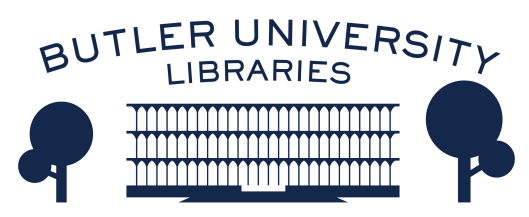

Journal of Hindu-Christian Studies

Volume 9

Article 6

January 1996

\title{
Texts are Always with You: Christians and their Bibles
}

R. S. Sugirtharajah

Follow this and additional works at: https://digitalcommons.butler.edu/jhcs

Part of the Religion Commons

\section{Recommended Citation}

Sugirtharajah, R. S. (1996) "Texts are Always with You: Christians and their Bibles," Journal of HinduChristian Studies: Vol. 9, Article 6.

Available at: https://doi.org/10.7825/2164-6279.1128

The Journal of Hindu-Christian Studies is a publication of the Society for Hindu-Christian Studies. The digital version is made available by Digital Commons @ Butler University. For questions about the Journal or the Society, please contact cbauman@butler.edu. For more information about Digital Commons @ Butler University, please contact digitalscholarship@butler.edu. 


\title{
Texts are Always with You: Christians and their Bibles
}

\author{
R. S. Sugirtharajah \\ Selly Oak Colleges, Birmingham
}

All stories have in them the seed of all other stories; any story, if continued long enough, becomes other stories, and she is no true storyteller who would keep this from you.

Vikram Chandra, Red Earth and Pouring Rain

WHAT CHRISTIANS CALL the Bible is a cultural, ideological, ritual, and spiritual depository of a people who lived in West Asia. Although Christians perceive it as the Book (in spite of the implied plural meaning in Greek), it is a composition of several books, embodying the collective and individual divine-human encounters of two communities - Jews and the early converts to the Jesus movement in the Mediterranean region. The Bible has two testaments, to which the adjectives "Old" and "New" are prefixed. These adjectival prefixes give the impression that the one is outdated, archaic, and no longer applicable, and the other is recent, interesting, and relevant. As cultural holdings, both are ancient and belong to a distant past, and are products of an alien culture. They are not neutral documents but were written by people who had definite ideological and theological perspectives. The Bible is a depository of the diverse textualized expressions of these people who articulated their experiences, over a long period, against different political, religious, and historical landscapes. Therefore, these texts do not necessarily present a single, unified, coherent perspective, but are riddled with partial perceptions, gaps, silences, and contradictions, which allow for multiple renderings, none of which can be exhaustive nor definitive.

The Bible is not an innocent document. Recently liberation, feminist, and AfricanAmerican theologians have scrutinized the biblical texts and exposed classism, sexism, and racism embedded therein. To these ideological biases, and as one who is part of the multi-religious context, I would like to add another - religionism. This is a concept introduced by John Hull, the Birmingham educationist and theologian, to describe the form of religion in which the identity of a group or individual is preserved by elevating one group whilst debasing the other. ${ }^{1}$ Religionism is about one faith tradition cultivating negative attitudes towards another religious tradition. Often, binary oppositional distinctions are reinvoked to maintain the difference and exclusivity - we are good, they are evil; we are believers, they are infidels; we are orthodox, they are heretical. Both the testaments, first and second, not only lend themselves to such interpretations but also embody such sentiments. For instance, in the New Testament the early Christians living among people of various religious persuasions conferred on themselves such high sounding titles as "saints", "the elect", "the called ones", "the people of God". The writer of 1 Peter reminds his readers that they are God's own people. The underlying implication of these epithets is to proclaim that Christians are different, their ways are different from those of others. The negative 
aspect of such a claim is that those who are outside the Christian fraternity are relegated to lesser theological categories, and not regarded as people of God.

One need not be conversant with recent hermeneutical theories in order to realize that it is different interpretative sites which inform, influence, and infuse biblical texts with meanings. The Bible acquires meaning when a community with a shared interest decides to invest it with a particular meaning. The Bible is capable of taking on different meanings in different interpretative sites. Each interpretative site has cultivated its own distinctive Bible. One can identify at least three different sites - parish, professional guild, and today's pluralistic arena. In order to draw out the distinctiveness of these sites, I suggest that we talk about three kinds of Bible - the Bible, the bible, and the Sacred Narrative. ${ }^{2}$ It is abundantly clear, however, that the use to which it is put in a parish is different from that in the academy or in the public arena, where it has to compete for textual credibility among a variety of equally valid and equally powerful sacred texts belonging to various faith traditions.

\section{The Bible in an Ecclesiastical Site}

The Bible in the parish context, whether protestant or catholic, is seen as a confessional document. Though these denominations have different sets of biblical books and arrange them in a different order, they perceive the Bible as providing "the starting point, foundation and norm" 3 for Christian living. The parish has harboured two types of Bible - the Bible as an object of veneration, and the Bible as a deposit of divinely guaranteed truth. Ordinary believers often handle the Bible in a non-readerly fashion, and treat it as an object of veneration. A deep sense of reverence is accorded, not necessarily to its contents, but to the mystical and magical powers it possesses as an artifact. To use Edward Said's words, spoken in a different context, the Bible "acquires a greater authority and use even than the actuality it describes". 4 More than because of its detailed account of events, people, and their experiences, the book is privileged because of its holiness and its transcendent properties. For instance, Wilfred Cantwell Smith tells of a nun who had grown up in a family in which a copy of the Bible, on the coffee-table in her living room, was always treated with extreme respect but it never occurred to any one of her family to open it and read it. ${ }^{5}$ A South Indian study among Christians reveals that the Bible is held in utmost awe, and is in danger of being deified. In homes and in churches a lamp is often placed near the Bible in the way a lamp is placed in the presence of an idol. ${ }^{6}$ It is also not uncommon to perform arati to the Bible or offer incense to it.

The parish has also fostered another Bible. The Bible is conceived of as the divine, progressively revealed Word of God, which culminated in the epiphany of Jesus. At times this is confusing because there is the tendency to equate and juxtapose the Word of God with Jesus, and the Bible with Christ. The Bible is used by the Church hierarchy because of its assured authoritative character and its prescriptive nature. It is seen as containing intrinsically within itself the indispensable, unique, and objective Word of God. This confessional axiom is repeatedly reinvoked during worship. After the reading of the lesson of the day, the worshippers are made to respond with the words, "This is the Word of God", instead of saying, "This is the Word of God in the words of Paul or Peter". ${ }^{7}$ In short, the Bible is the word of God. Accordingly, it becomes the reference point for Christian faith and provides the norm and source for Christian life. Any new moral, ethical, or doctrinal issue is settled, not by historically situating the text, but by transposing the present time to the biblical time, and by quoting the texts in a proof-text manner without paying any attention to historical and cultural differences between the two contexts. Any attempt to contextualize the Gospel is seen 
as giving in to relativism. The presupposition is that there is one common unredeemed humanity, running through history, which is in need of grace and salvation. It considers that the Bible, irrespective of time and place, has within its pages a mandate, an assurance, a caution, and an example to emulate and/or a mistake to avoid. The Bible is regarded as allsufficient for Christian nurture and growth, and it is also seen as a court of appeal: "It is a critical court of appeal to which the Church must constantly defer and from whose judgement not even the developments taking place in our world are exempted". ${ }^{8}$

\section{The Academy and its Bible}

The concerns of the academy are different from those of the community of faith. Up until now, in the academy, the Bible has been regarded as an historical document. With a recent paradigmatic shift within academic circles, however, it is increasingly being seen as a literary artifact, one which embeds in its pages various literary patterns which enable the narrative to communicate meanings. In its appropriation of the Bible, the academy is not unduly prompted by traditional church questions. It is more concerned with the historical and literary nuances of the text than with its theological or doctrinal significance for the believers. In its attempt to retrieve the historical and literary heritage of the texts, the academy does not limit or confine itself only to the canonical writings mandated by the church. It feels free to enlarge the documentary evidence, and it draws on and delves into wider extracanonical literary data - Nag Hammadi codices, Dead Sea scrolls, Cynic materials - the very writings viewed with suspicion by the church. The foregrounding of such materials, which were viewed as being of doubtful value by the recent Jesus questers, is a case in point. In order to distinguish the way the Bible is seen in the academy, the bible (with lower case) may be a convenient way of drawing the distinction. $^{9}$
The academy seeks to understand the bible in terms of the norms and techniques set by the professional guild. It sets itself the task of retrieving the original message by applying a variety of critical tools and methods. The application of a plurality of critical methods - historical, literary, and social-scientific - to retrieve the "intended" or "implied" meaning of the biblical narratives or biblical authors, has inevitably led to different contours within the bible. Historical-critical criticism views the Bible as consisting of occasional and contextual writings which emerged through a long process of writing and rewriting. Canonical criticism, on the other hand, does not see the biblical materials in their immediate historical context, nor as narrow isolated units, but sees them within the context of the entire canon. Redaction criticism sees the Bible as a product of the theological quest of different biblical writers. Social science criticism understands the Bible as the deposit of the social, economic, and political history of Israel and the early Jesus movement. Structuralism engages with the text as a communicative system. Literary criticism tends to deal with the literary concerns and "poetic function" of the texts.

The academy may not view the Bible as the truth, but it sees it as a witness to the truth. As Ernst Kasemann puts it, only in its pages does one encounter the Gospel. ${ }^{10}$ The academy, however, does not see its task as seeking hermeneutical connections between the historical context of the text and current theological concerns. The reason given by Julius Wellhausen, the Old Testament scholar, when a hundred years ago he changed from the theological to the philosophical faculty, encapsulates the mood of the academy. In a letter to the Minister of Education, he explained his move:

I became a theologian because I was interested in the scientific treatment of the Bible. It was only in the course of time that I realized that a professor of theology has also the practical task of preparing the students for their ministry 
in the church. I realized that I was unable to meet this requirement. I am afraid to make the students rather incapable for their ministry. ${ }^{11}$

\section{Sacred texts in a Pluralistic Textual Arena}

In today's pluralistic textual arena, the Christian scriptural tradition which calls itself the Book loses its privileged status and is counted as but one among many such sacred texts. In such a plurality of textual traditions, the Christian Bible, which denied and silenced other competing scriptural texts, manifests itself as a sacred narrative. It ceases to be the "Grand Story" in the market place of many religious texts. Rather, it is perceived as one sacred narrative told within the parameters of a community, and set beside other communally inspired sacred stories.

In the pluralistic textual arena, all scriptural narratives are seen as partial and localized versions of the reality. No scripture narrates the full story of the reality; it offers only a few glimpses of it. A comparative hermeneutics of different scriptures can prompt us to see the often neglected and marginalized aspects of another tradition. The Christian scripture is often read, and rightly so, against Semitic and hhellenistic backgrounds. It will be enriched if it is read in conjunction with Indic religious texts and stories. Such a wider inter-textual reading will light up and fill the gaps in biblical texts. For instance, Ishand Vempany, in his study of the Bhagavadgita and the New Testament, demonstrates how, in selectively interpreting one aspect of the tradition, both Hindus and Christians missed out other equally valuable features. For example, he reminds Hindus of how, in their over-focused emphasis on other-worldly mystical elements, they have largely disregarded the Hindu ethic of caring for the poor. In turn, he reminds Christians of how, under the influence of the "cross factor", they have forgotten the Christian aspect of ananda, - joy, cheer, charm, and humour - which is implicit in their texts. ${ }^{12}$ Similarly, George Soares-Prabhu has exegetically demonstrated how two missionary commands - the Buddhist (Mahavagga 1.10-11.1), and the Christian (Mt.28.16-20) - when read interactively, can arrive at a fuller interpretation. His hope is that such a wider intertextual reading will begin to "reveal the biblical way to the "disinterested action (nishkāma karma) of the Bhagavadgita $(2.47 ; 4.18-20)$, or to that unshakable "calm" (sāntam), like that of a deep lake clear and still, which in the Dhammapada $(6.7 ; 7.7)$ is the mark of a "saint" ("arhant") 13

\section{Hermeneutical Observations}

There is a tendency to assume that the Bible has answers for all our questions and that it is a source of true knowledge. But what is interesting to note is that the Bible did not even provide answers for some of the critical questions which came up in its own time. When the early Church movement extended out of its Palestinian rural milieu and began to attract Gentile converts it was faced with a number of practical and everyday questions. Questions such as: do these Gentile converts need to be circumcised? or: can a Jewish Christian and Gentile Christian intermarry? or: can Jewish Christians eat with Gentiles at public functions? To these pressing questions, the early Jesus movement did not have any dominical sayings to guide them. There were no warrants from Jesus because he himself did not have to face these questions. $\mathrm{He}$ came from northern Palestine and grew up in its rural environs. Geographically his activities were confined to the Jewish regions, mainly Galilee - the hot-bed of Jewish nationalism. He was not particularly remembered for any explicit dealings with the Gentiles, nor was he always generous to those who were not part of the Jewish race. He called them "dogs" and found them not worthy enough to eat the bread belonging to the children of Israel (Matt.15.26, Mk.7.27). He did not think much of the 
Gentile piety and found that the prayer of the Gentile was a vain noise (Matt.6.7). $\mathrm{He}$ encouraged his disciples to go only to the lost sheep of the house of Israel, and wouldn't have envisaged that his message would attract non-Jews. In his celebrated encounters with the Canaanite woman, the centurion, and the Gaderene demoniac, the initiative came from these Gentiles, and none of them expressed any wish to be part of his movement. He expressed the purpose of his ministry to the Canaanite woman thus: "I was sent only to the lost sheep of Israel" (Matt.15.24). Since he did not have to face the questions confronting the members of the early Jesus movement, there is no help or hint from Jesus.

Faced with a fresh set of questions, Paul and the leaders of the early Jesus movement did not despair nor abdicate their responsibility. They agonized, struggled, and came up with answers - not always correct, often fudged and compromising (as the decisions of the Jerusalem council demonstrate (Acts 15). They believed, however, that they were the relevant answers for their time. We need to take a cue from Paul and his contemporaries and work out our solutions without being overawed by the past, and without finding comfortable sanctuary in texts. As Wilfred Cantwell Smith put it, "the basic question is not about scripture, but is about us". 14

The Christian scriptures are quintessentially, to use Christopher Duraisingh's phrase, "an earlier paradigmatic instance". As such biblical records are not to be blindly copied. Duraisingh goes on to write, "For a paradigm is not a blueprint but an exemplary instance with an evocative power to bring about an analogous, life-giving response in the present". 15 We constantly go back to these documents, not because they are a divinely guaranteed source of truth, but because they help us to discern again what it means to be part of that ongoing community. In reading these pages, our focus is not on texts alone, but also on people and their concerns. If we recognize that the world of the Bible is a fragmented world, its social structures fractured, and its people fallible, then we might start to see more clearly our own fragmented world, our own imperfect social systems, and our human weakness. We must have the hermeneutical integrity to admit the difference between our context and theirs. But if we listen carefully we may rediscover in their stories and struggles our own anxieties, hopes, and questions. The documents may not possess the answers, but they may encourage us in the present and excite our imagination to act creatively and to map out an open future.

\section{Notes}

1. John M. Hull, "Transmission of Religious Prejudice", British Journal of Religious Education, 14, 2 1992, p.70.

2. See Philip R. Davies, Whose Bible is it Anyway? Sheffield: Sheffield Academic Press, 1995. He argues for different bibles. Though there are similarities between our classifications, mine differs from his in that his is solely placed in the Christian mode and does not take note of the textual traditions of other faiths.

3. The Pontifical Biblical Commission: Interpretation of the Bible in the Church, Rome: Libreria Editrice Vaticana, 1993, p. 123.

4. Edward Said, Orientalism, Harmondsworth: Penguin Books, 198 p. 93.

5. Wilfred Cantwell Smith, What is Scripture? Minneapolis: Fortress Press, 1993, pp.2345.

6. G.D. Melanchton, "Impact on the Christian Attitude to Scripture", in: Influence of Hinduism on Christianity, Gnana Robinson (Ed.), Madurai: The Tamilnadu Theological Seminary, 1980 , p. 87.

7. I owe this point to Elisabeth Schüssler Fiorenza. See: Bread not Stone: The Challenge of Feminist Biblical Interpretation, Boston: Beacon Press, 1984, p.25.

8. Faith and Order - Louvain 1971: Faith and Order Paper No. 59, Geneva: WCC, 1971, 
p.11. Indic faiths.

9. See Philip Davies, Whose Bible is It Anyway? p. $20 \mathrm{ff}$.

10. Ernst Kasemann, Essays on New Testament Themes: Studies in Biblical Theology No.41, London: SCM Press, 1964, p.57

11. Friedrich Huber, "Towards an ApplicabilityAimed Exegesis", Indian Journal of Theology, 20, 1980, p.135.

12. Ishand Vempany, Krsna and Christ: in the light of some of the fundamental concepts and themes of the Bhagavad Gita and the New Testament, Pune: Ishvani Kendra, 1988.

13. George Soares-Prabhu, "Two Mission
Commands : An Interpretation of Matthew 28:16-20 in the light of a Buddhist Text", Biblical Interpretation: $A$ Journal of Contemporary Approaches, 2, 3, 1994, p.273.

14. Wilfred Cantwell Smith, What is Scripture?, p. 242.

15. C. Duraisingh, "God in Jesus Christ - The life of the World: Reflection from an Asian Perspective", Jesus Christ with People in Asia. Report of the Asian Consultation in Singapore, July 1982, on the theme: Jesus Christ - The life of the World, Singapore: CCA, (no date) p.41. 